\title{
The Determinants of Life Insurance Demand: A Focus on Saving Motives and Financial Literacy
}

\author{
Nurul Shahnaz Mahdzan ${ }^{1} \&$ Sarah Margaret Peter Victorian ${ }^{2}$ \\ ${ }^{1}$ Faculty of Business \& Accountancy, University of Malaya, Kuala Lumpur, Malaysia \\ 2 Transformation Management Office, Am Assurance Berhad, Selangor, Malaysia \\ Correspondence: Nurul Shahnaz Mahdzan, Department of Finance \& Banking, Faculty of Business \& \\ Accountancy, University of Malaya, 50603 Kuala Lumpur, Malaysia. Tel: 60-3-7967-3958. E-mail: \\ n_shahnaz@um.edu.my
}

Received: February 19, 2013 Accepted: March 21, 2013 Online Published: April 27, 2013

doi:10.5539/ass.v9n5p274 URL: http://dx.doi.org/10.5539/ass.v9n5p274

\begin{abstract}
This paper investigates the determinants of life insurance demand among life insurance policyholders of five major life insurance companies in Kuala Lumpur, Malaysia. From a sample of 259 individuals, the study analysed the influence of demographic variables, saving motives and financial literacy, on life insurance demand To determine the relationship between the demographic factors and life insurance demand one way ANOVA tests were conducted. The relationship between financial literacy and saving motives (precautionary, bequest, life cycle and wealth accumulation motives) with life insurance demand was then analysed using a multiple regression. Results revealed that demographic variables and saving motives were significantly related to life insurance demand. Financial literacy, however, was found to be insignificant in determining life insurance demand.
\end{abstract}

Keywords: life insurance demand, saving motives, precautionary, life cycle, bequest, wealth accumulation

\section{Introduction}

Life insurance plays an important role in an individual's personal financial plan, as suggested by most personal finance and financial planning books. Life insurance helps individuals save money while protecting against personal risks in life. However, financial planners and representatives of life insurance companies would attest that many individuals are often reluctant to allocate funds in life insurance and fail to see its underlying benefits as a personal risk management tool. This phenomenon is evident in a report by Life Insurance Association of Malaysia or LIAM (2011)stating that only 42 percent of the total Malaysian population are insured -- implying that the remaining 58 percent of the population is still vulnerable to life's risks that may permanently strip away their future earnings.

The relatively high proportion of uninsured population in Malaysia may be viewed from two different perspectives. From one perspective, such situation raises concern on the vulnerability of dependents should sudden death of the family's breadwinner occurs. From another perspective, low holdings of life insurance suggest that there is ample room for growth in Malaysia's insurance industry. The life insurance industry registered a commendable growth as reported by LIAM (2011) where a growth of 11.9\% (RM 8.42 billion) was reported in 2010 compared to 9\% (RM 7.53 billion) in 2009.

Compared to other, more developed countries in Asia, life insurance business in Malaysia contributes $2.8 \%$ of GDP as opposed to $6.1 \%$ in Singapore and 7.5\% in Japan. The Malaysian government is in full support of efforts by the financial services sector to increase life insurance ownership among Malaysians. The Malaysian government intends to increase contribution toward GDP to 4\% with 75\% of the population insured by 2020 - in line with various initiatives of the Economic Transformation Program (ETP) in which the Malaysian government is steering the nation towards becoming a high income economy (Dhesi, 2012)

Efforts to boost the life insurance industry may be undertaken from either the demand or supply side of the market. From the demand side, increased financial literacy may increase society's awareness regarding the benefits of life insurance. From the supply side, increased understanding of consumers' motivations of purchasing life insurance would improve financial services' marketing efforts of increasing life insurance 
penetration.

Despite numerous researches on the issue of life insurance, there are still gaps in the body of knowledge especially in terms of understanding the motives behind life insurance demand. This issue is explored in the context of Malaysia, where the underlying motives of individuals in their allocation into life insurance will be investigated. In particular, the influence of saving motives (precautionary, life cycle, bequest and wealth accumulation) on life insurance demand will be examined. In addition, the relationship between socio-demographic variables and financial literacy with life insurance demand will also be investigated.

\section{Literature Review}

\subsection{The Demand for Life Insurance}

Theoretical underpinnings on life insurance demand date back to the 1960s with works by Yaari (1965) in which theoretical frame works for life insurance demand were developed. In Yaari's framework the demand for life insurance is attributed to a person's desire (or a "joy of giving") to bequeath funds to dependents and provide income for retirement. It was posited that the demand for life insurance is a function of wealth, expected income over a person's lifetime, interest rates, the cost of life insurance policies (e.g. administrative costs) and the assumed subjective discount on current over future consumption.

More recently, Beck and Webb (2003) extended the earlier framework by incorporating the preferences of dependents and beneficiaries into the model. The authors conjectured that demand for life insurance increases with probability of the primary wage earner's death, the present value of the beneficiary's consumption, and the degree of risk aversion. On the other hand, life insurance demand decreases with the policy loading factor and the household's wealth.

Traditionally, life insurance was purchased to leave a certain amount of funds for beneficiaries to be able to pay for burial expenses of the deceased (i.e. the insured). In more recent years, however, the role of life insurance has become increasingly more significant. Todd (2004) suggested that life insurance replaces a lost stream of income that results from the death of an individual. In face of increasing urbanization, mobility of the population and formalization of economic relationships between individuals, families and communities, life insurance has taken a more important role as a way for individuals and families to manage financial risk (Beck and Webb, 2003).

A more holistic and contemporary view on the role of life insurance is that I tis purchased to manage income risk, that is, the risk of losing income due to major disruptions of income earning ability due to death or a permanent disability. New innovations in life insurance also provide long term saving and investment opportunities for individuals, as insurance companies now offer endowment and investment-linked type of policies that serve an accumulation purpose. Life insurance is a means of disciplined contractual saving and a key source of long term accumulation of finances (Beckand Webb, 2003).

\subsection{The Determinants of Life Insurance Demand}

\subsubsection{Socio Demographic Factors}

Marital status. Some families plan for one spouse to "remain" at home for his or her lifetime should the other spouse die prematurely, with the survivor taken care of by life insurance proceeds. However, the amount of Life insurance decreases as the person gets older ceteris paribus, because it takes a greater total sum of money (i.e. premium) to support older individuals as opposed to younger ones(Dorfmanand Adelman, 2002).

From a psychological point of view, Abraham Maslow viewed the act of purchasing life insurance by married individuals as a sense of safety in which a surviving spouse would be financially secured should the other lose income ability (Dorfman \& Adelman, 2002).

Education. The level of education is positively related to the demand for life insurance in two respects. Truett and Truett (1990) suggest that people with higher education attainment is associated with a stronger desire and awareness to protect dependents and safeguard their standard of living. Browne and Kim (1993) explained that higher level of education results in greater awareness of life's uncertainties, therefore leading to higher life insurance coverage.

In prior research, level of education by tertiary gross enrolment ratio (regardless of age) was used as a measure to determine the level of education and was found to be positively related to the demand of life insurance ( $\mathrm{Li}$, Moshirian, Nguyen \& Wee, 2007).

Income. Household disposable income has been found to be positively associated with household saving. For example, Perry and Morris (2004) found that people with higher incomes were more likely to engage in responsible financial management behaviours, such as saving money or investing in other means of saving 
channels (Delafrooz \& Paim, 2011).All theories related to income and savings growth rate suggested that increase in investment rate is resultant from an increase in income (Raza, Farhan \& Akram, 2011).

Dependents. Some individuals are responsible for the care and financial support of a permanently disabled child, spouse or parent. The financial problems caused by death of the caregiver during the disabled person's life can often be met with life insurance (Dorfman \& Adelman, 2002). While disabilities may be permanent, life insurance acts as a safety net to provide coverage for a life time. Hence, the probability of a breadwinner purchasing life insurance with such dependents is expected to be high. Furthermore, it was found that the probability of having life insurance was negatively correlated with age, but positively correlated with the presence of children. The latter finding supports the view that individuals with children have a stronger propensity to leave bequeathable wealth in the form of life insurance.

\subsubsection{Financial Literacy}

Financial literacy has been described as the ability to plan ones' finances effectively by utilizing savings to accumulate wealth, followed by careful preservation of such wealth against value depreciation and losses, and finally, distribution of wealth at a later stage of one's life. Generally, research has found that individuals with high financial literacy are more likely to engage in financial planning, including investing in unit trust and purchasing life insurance, as opposed to individuals with lower levels of financial literacy.

Lusardi, Mitchell and Curto (2010) found that people with low financial literacy are less likely to accumulate wealth and less likely to plan for retirement; and that financial literacy is important for sound financial decision making. Financial literacy boosts the ability in handling day to day financial matters and will reduce the negative consequences of poor financial decisions that might otherwise take years to overcome (Delafrooz and Paim, 2011).

Shafii, Abiddinand Ahmad (2009) concluded that increased financial literacy brings about higher participation of individuals in financial planning activities such investment in shares, property and life insurance.

\subsubsection{Saving Motives}

The literature has established four main aspects of saving motives - precautionary motives (Hubbard et al., 1995), life-cycle motives (Modigliani \& Brumberg, 1954), bequest motives (Bernheim, Shleiferand Summers, 1985), and wealth accumulation or profit motives (Keynes, 1936). These will be further discussed in the following sub-sections.

Precautionary Motive. Precautionary motive refers to efforts undertaken by individuals to reduce the uncertainties in life. According to Wärneryd (1999, p. 270), "insurance is a remedy against the feeling of uncertainty in the sense that there is preparedness for facing the consequences of the ill outcomes that uncertainty may embody". Hence, it can be posited that the demand for life insurance is influenced by precautionary motives, as life insurance protects against personal risks such as life, health and disability risks. Abel (1985) asserted that a precautionary demand for saving arises because an individual consumer does not know in advance the date at which he will die, and he avoids low level of consumption in the event that he lives longer than expected and will opt to purchase life insurance as a precaution for the use of future consumption.

Life Cycle Motive. The life-cycle motive for saving is based on the notion by Modigliani and Brumberg (1954) asserting that individuals tend to smooth out their consumption and save money to prepare for major life cycle events and expenses that may occur later in life, such as a wedding, to purchase a house, for education purposes or to have a child. A similar argument was made by Liebenberg et al. (2010) who asserted that life insurance purchases are likely to follow various "life events", such as marriage, the birth of a child, purchasing a home, and a new job; and that, similarly, termination of life insurance is likely to follow other life events such as divorce, death of a spouse, unemployment and retirement.

Bequest Motive. The bequest motive refers to intentions of leaving an inheritance to the next of kin or dependents (Bernheim et al., 1985).Li et al. (2007) suggested that bequest motives influences the demand for life insurance. This was associated to the findings of Bernheim (1991) demonstrating that a strong motive for saving amongst U.S. households with bequest motive. Fitzgerald (1987) found that life insurance purchases are based on how well off a couple chooses to leave the survivors if both members had lived.

Wealth accumulation motive. The literature also suggests that individuals save to accumulate capital, or in other words, to make a 'profit' from their savings (see Wärneryd, 1999, p. 277). Diacon and Mahdzan (2008) assessed the changes in wealth accumulation in relation to changes inrisk and argued that households will want to conserve more wealth when they are faced with greater uncertainty - such as the potential fluctuations in future income and sudden out-of-pocket medical expenses and thus increasing the demand for life insurance. 
When examining the risk effects on financial net worth and total net worth, Lusardi et al. (2010) found significant evidence of precautionary savings, such that people who faced higher income risk also saved and accumulated more wealth. Results also indicated that households who were more risk averse, and who had long planning horizons accumulated more wealth - suggesting that risk aversion and prudence are positively related wealth accumulation and investment in life insurance.

Having discussed the factors that influence life insurance demand, Section 3 follows by detailing the methodology undertaken for this study.

\section{Methodology}

\subsection{Sampling Method}

This study employed a non-probability sampling method whereby data was collected on a sample of 259 life insurance policy holders of five major life insurance companies in Kuala Lumpur Malaysia. This purposeful sampling method was chosen as it aims to delve into the key factors motivating life insurance purchase amongst those who already own life insurance policies. Approximately 1,000 paper and online version of the questionnaire was distributed. Out of these, only 275 were returned with only 259 of them deemed usable.

\subsection{Instrument}

The instrument used was a self-administered questionnaire consisting of three sections. Section I asked about ownership of life insurance policy (number of policies, annual premium paid and type of life insurance policy owned). Section II asked about motives for life insurance holdings (life-cycle, precautionary, bequest and wealth accumulation) and also financial literacy. Section III requested for some demographic information of respondents.

\subsection{Research Framework}

Based on the literature review, this study posits that demographic variables, motives and financial literacy influence the demand for life insurance. The research framework is shown in Figure 1 below:

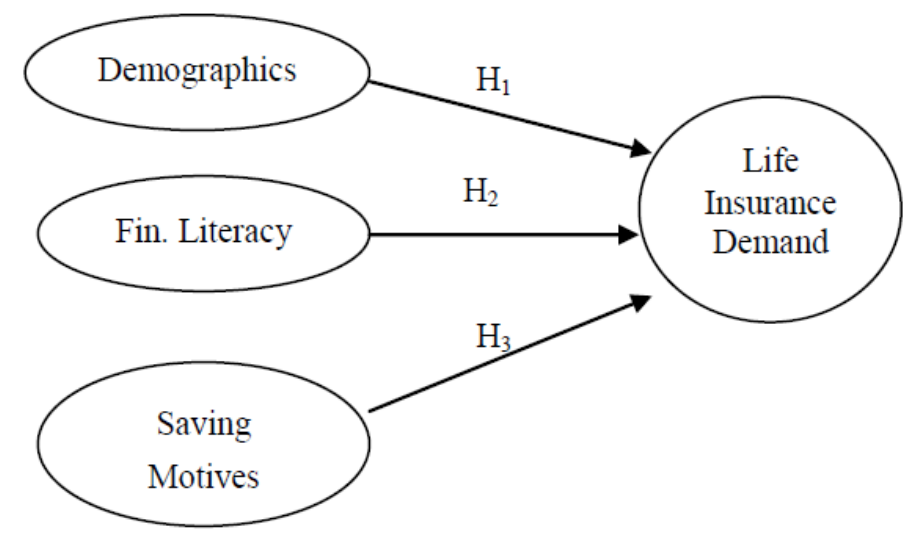

Figure 1. Determinants of life insurance demand

\subsection{Measurement of Variables}

\subsubsection{Dependent Variable: Life Insurance Demand}

The dependent variable in this study is life insurance demand. In economics, "demand" is defined as the willingness and ability of individuals to consume a certain product or service. Accordingly, in the context of this study the demand for life insurance was measured asa continuous variable of the approximate annual premiums that respondents were willing and able to pay for a life insurance policy, in the Malaysian currency, Ringgit Malaysia (RM).

\subsubsection{Independent Variables}

Demographic variables. The independent variables were divided into three main components which are demographic variables, motives for saving, and financial literacy. All socio-demographic variables (marital status, education, income, number of dependents) were measured as categorical variables.

Financial Literacy. Financial literacy was measured using five (5) items in which the respondents were asked to 
self-rate their knowledge and understanding regarding life insurance. For example, they were asked whether they fully understood the life insurance plan purchased; the riskiness of their life insurance plans; the financial product best fits their financial needs; and the other financial products that best fits their needs. The variable for financial literacy was measured using a 5-point Likert scale ranging from 1 (strongly disagree) to 5 (strongly agree).

Saving Motives. Motives were measured using a 5-point Likert scale ranging from 1 (strongly disagree) to 5 (strongly agree). Life-cycle motives were measured using four (4) items to determine whether life insurance was purchased for children's education, for retirement, wedding expenses, or for a new-born child. Precautionary motives were measured using three (3) items in which respondents were asked whether they purchased life insurance for emergency purposes, for a rainy day or in the unfortunate event of disability. Bequest motives were measured as a series of three (3) items asking whether life insurance was purchased for the dependents in the absence of the breadwinner, to leave as an inheritance, or as a continuity of income upon death. Wealth accumulation motives were measured using four (4) items in which respondents were asked if they purchased life insurance as a form of savings, to obtain guaranteed returns, or for its bonuses and dividends.

\subsection{Hypotheses}

The hypotheses to be tested in this study are as follows:

Hypothesis 1: There are significant differences between demographic categories and the demand for life insurance.

Hla: There are significant differences between marital status groups and their demand for life insurance.

$H 1 b$ :There are significant differences between number of dependents categories and the demand for life insurance.

H1c: There are significant differences between income groups and the demand for life insurance.

H1d:There are significant differences between education attainment groups and the demand for life insurance.

Marital Status: It is predicted that married individuals have a higher probability to purchase life insurance compared to individuals who are single simply because they are responsible for their spouses and children's financial freedom in the event of loss of future income.

Number of Children: It can be expected that the number of children may be positively related to the demand for life insurance, as this will be related to a greater sense of responsibility towards children's finance's in the future.

Level of Income: This study posits that income will be positively related to life insurance demand because individuals with higher income groups have more money to save (assuming other factors constant).

Education Level: It is hypothesized that education level will have a positive impact on individual saving with higher demand for life insurance. Higher education levels imply that those people have a better understanding of their personal financial matters, so they will be better able to make financial decisions and have more ability to plan for their future. There is evidence to show that more educated people can manage their money in terms of insuring, investing, saving and budgeting (Hogarth, 2002).

Hypothesis 2: Saving motives are positively related to life insurance demand.

$H 2 a$ :Precautionary motives are positively related to life insurance demand.

$H 2 b$ : Life cycle motives are positively related to life insurance demand.

$H 2 c$ : Precautionary motives are positively related to life insurance demand.

$H 2 d$ : Wealth accumulation motives are positively related to life insurance demand.

Precautionary motive: It is hypothesized that precautionary motives will have a positive impact on individual saving and greater demand for Life insurance because those individuals with precautionary motive are inclined to avoid the risk of loss of income in the event of a life crisis.

Life Cycle motive: It is expected that life cycle motives will have a positive impact on demand for Life insurance because these individuals with life cycle motive are highly likely to invest in some form of saving at present to avoid the ensure financial security in the future to face any life cycle event such as a expenses for a new born, education and wedding expenses or burial expenses.

Bequest motive: The bequest motive is expected to have a positive impact on demand for life insurance as individuals with bequest motives are concerned about leaving an inheritance for their loved ones in the event of their death. 
Wealth accumulation motive: Individuals with wealth accumulation motives are expected to have a higher demand for life insurance as they perceive life insurance as a form of savings and want to accumulate funds for future use.

Hypothesis 3: Individual's financial literacy is positively related to the demand for life insurance.

Financial Literacy: It is posited that financial literacy has a significant impact on life insurance demand, as more knowledge on financial matters will enable individuals to make more substantive financial plans and more informed decisions regarding allocations of their money and saving. It is predicted that the relationship between financial literacy and demand for life insurance is positive.

\subsection{Analyses}

Three main types of analyses were conducted. First, descriptive analyses were carried out on the demographic variables and dependent variable (life insurance demand). Second, one-way ANOVA tests were conducted to test Hypotheses 1a-1d. This analysis is chosen because the independent variables (socio-demographic variables) are categorical in nature and the dependent variable (life insurance demand) is continuous. The third type of analysis conducted was a multiple regression on the dependent variable, regressed on five independent variables, namely financial literacy, precautionary motive, bequest motives, life cycle motives, and wealth accumulation motives.

The model specification for hypothesis 2 and 3 is as follows:

$$
\text { LI_DEMAND }=a+\beta_{1} \text { FIN_LIT }+\beta_{2} \mathrm{PREC}+\beta_{3} \mathrm{LC}+\beta_{4} \mathrm{BEQUEST}+\beta_{4} \text { WEALTH_ACC }
$$

where $a$ is a constant, LI_DEMAND denotes the demand for life insurance, FIN_LIT refers to financial literacy, PREC refers to precautionary motives, LC is the life cycle Motive, WEALTH_ACC relates to wealth accumulation motives; and $\beta_{n}$ are the coefficients to be tested.

\section{Results}

\subsection{Descriptive Analysis}

Socio-demographic variables. From a total of 259 respondents, $67.6 \%$ were female while the other $32.4 \%$ were male respondents. In terms of ethnicity, the respondents were quite a balance between $32.4 \%$ (Chinese), 30.5\% (Malay) and 27.8\% (Indian). As for marital status, 50.6\% were married, 40.2\% were single while $9.3 \%$ were divorcees. Out of the total number of respondents, $48.9 \%$ had one dependent, $21.2 \%$ had two dependents, $20.8 \%$ had no dependents while $9.3 \%$ had a total of three dependents. For educational level, respondents are made up of 41.3\% (Diploma/College educated), 39.8\% (Secondary educated) and 18.9\% (Undergrad/Postgraduate educated) In terms of monthly income, $35.9 \%$ of the respondents earned between RM 2,000 and RM 2,999, 25.9\% earned between RM 4,000 and RM 4,999, 18.1\% earned between RM 1,000 and RM 1,999, 14.7\% earned between RM 3,000 and RM 3,999 while there was a minority on both extremes of 3.1\% earning less than RM 1,000 and $2.3 \%$ earning more than RM 5,000.

Table 1. Socio-demographic profile of respondents

\begin{tabular}{|c|c|c|c|}
\hline Characteristics & Categories & Frequency & Percentage \\
\hline \multirow[t]{3}{*}{ Gender } & Male & 84 & 32.4 \\
\hline & Female & 175 & 67.6 \\
\hline & Total & 259 & 100.00 \\
\hline \multirow[t]{5}{*}{ Age } & Below 20 & 24 & 9.3 \\
\hline & $21-30$ & 79 & 30.5 \\
\hline & $31-40$ & 104 & 40.2 \\
\hline & $41-50$ & 52 & 20.1 \\
\hline & Total & 259 & 100.0 \\
\hline \multirow[t]{5}{*}{ Race } & Malay & 79 & 30.5 \\
\hline & Chinese & 84 & 32.4 \\
\hline & Indian & 72 & 27.8 \\
\hline & Others & 24 & 9.3 \\
\hline & Total & 259 & 100.0 \\
\hline
\end{tabular}




$\begin{array}{llcc}\text { Marital Status } & \text { Single } & 104 & 40.2 \\ & \text { Married } & 131 & 50.6 \\ & \text { Divorced } & 24 & 9.3 \\ & \text { Total } & \mathbf{2 5 9} & \mathbf{1 0 0 . 0} \\ & \text { Primary } & 7 & 2.7 \\ & \text { Secondary } & 100 & 38.6 \\ & \text { Diploma/College } & 103 & 39.8 \\ & \text { Undergrad/Postgraduate } & 49 & 18.9 \\ \text { No. of Dependents } & \text { Total } & \mathbf{2 5 9} & \mathbf{1 0 0 . 0} \\ & \text { None } & 54 & 20.8 \\ & 1 & 126 & 48.9 \\ & 2 & 55 & 21.2 \\ & \text { 3 } & 24 & 9.3 \\ & \text { Total } & \mathbf{2 5 9} & \mathbf{1 0 0 . 0} \\ \text { Monthly Income } & \text { Less than RM 1,000 } & 8 & 3.1 \\ & \text { RM 1,000 - RM 1,999 } & 47 & 18.1 \\ & \text { RM 2,000 - RM 2,999 } & 93 & 35.9 \\ & \text { RM 3,000 - RM 3,999 } & 38 & 14.7 \\ & \text { RM 4,000 - RM 4,999 } & 67 & 25.9 \\ & \text { RM 5,000 and above } & 6 & 2.3\end{array}$

Total

259

100.0

Life insurance demand. As explained earlier, life insurance demand is measured as a continuous variable whereby respondents were asked to indicate the actual or approximate amount of premiums paid annually for their Life insurance policies, in Ringgit Malaysia. The mean score for annual premiums paid is RM 1,280 as shown in Table 1.

Table 2. Mean value of annual premiums paid

\begin{tabular}{ccc}
\hline LI_DEMAND & Annual premiums & Std. Deviation \\
\hline Mean & $1,280.2471$ & 792.36105 \\
\hline
\end{tabular}

\subsection{Determinants of Life Insurance Demand}

\subsubsection{Socio-Demographic Variables}

Marital Status. Results of the ANOVA test as shown in Table 3 suggest that there are significant differences between marital status groups and their demand for life insurance $(\mathrm{F}=8.195, \mathrm{Sig}=.000)$, supporting hypothesis H1a. Life insurance is mostly purchased by single individuals, followed by married individuals and is least bought by individuals who are divorced. A possible reason is because single people find that they may not have anyone to depend on in the event a major health crisis such as a disability or critical illness and hence, need to rely on life insurance policies. Furthermore, single individuals may have less financial commitments as opposed to married individuals and have the ability to allocate funds into life insurance. 
Table 3. One way ANOVA: Marital status and demand for life insurance

\begin{tabular}{lcccc}
\hline Marital Status & $\mathrm{N}$ & Mean & Std. Deviation & Std. Error \\
\hline Single & 104 & 1485.3750 & 861.83743 & 84.51011 \\
Married & 131 & 1196.2519 & 733.80555 & 64.11289 \\
Divorced & 24 & 849.8333 & 499.10465 & 101.87931 \\
Total & $\mathbf{2 5 9}$ & $\mathbf{1 2 8 0 . 2 4 7 1}$ & $\mathbf{7 9 2 . 3 6 1 0 5}$ & $\mathbf{4 9 . 2 3 4 9 2}$ \\
\hline
\end{tabular}

DV:LI_DEMAND, F= 8.195, Sig=.000

Education. Results of ANOVA as shown in Table 4 suggest that there are significant differences between the groups of the level of education and their demand for Life insurance $(\mathrm{F}=104.527, \mathrm{Sig}=.000)$. It can be inferred from the table above that education level is positively related to life insurance demand. Therefore, hypothesis $\mathrm{H} 1 \mathrm{~b}$ is accepted.

Table 4. One way ANOVA: Education level and life insurance demand

\begin{tabular}{lcccc}
\hline Level of Education & $\mathrm{N}$ & Mean & Std. Deviation & Std. Error \\
\hline High School & 107 & 791.1600 & 428.68280 & 42.86828 \\
Diploma & 103 & 1253.6990 & 550.55350 & 54.24765 \\
Degree and above & 49 & 2415.0408 & 695.63200 & 99.37600 \\
Total & $\mathbf{2 5 9}$ & $\mathbf{1 2 8 0 . 2 4 7 1}$ & $\mathbf{7 9 2 . 3 6 1 0 5}$ & $\mathbf{4 9 . 2 3 4 9 2}$ \\
\hline
\end{tabular}

DV: LI_DEMAND, F=104.527, Sig=.000

Number of dependents. Table 5 shows the relationship between the number of dependents and the purchase of life insurance. Results of ANOVA show that there are significant differences between the groups of the number of dependents under ones care and their demand for Life insurance $(\mathrm{F}=11.122, \mathrm{Sig}=.000)$, thus supporting hypothesis H1c. These results show that individuals with three dependents have the highest demand for life insurance, followed by individuals with no dependents, one dependent, and lastly, two dependents.

Table 5. One way ANOVA: Number of dependents and demand for life insurance

\begin{tabular}{lcccc}
\hline Number of Dependents & $\mathrm{N}$ & Mean & Std. Deviation & Std. Error \\
\hline None & 54 & 1271.7593 & 912.19929 & 124.13460 \\
1.00 & 126 & 1254.0397 & 765.58506 & 68.20374 \\
2.00 & 55 & 1008.4182 & 479.43924 & 64.64757 \\
3.00 & 24 & 2059.8750 & 765.00312 & 156.15561 \\
Total & $\mathbf{2 5 9}$ & 1280.2471 & 792.36105 & 49.23492 \\
\hline
\end{tabular}

DV: LI_DEMAND, $F=11.122$, Sig $=.000$

Income level. Table 6 shows the relationship between level of income and the purchase of life insurance. Results of ANOVA show that there are significant differences between the groups of income and their demand for Life insurance $(\mathrm{F}=5.861, \mathrm{Sig}=.000)$. The results show a clear pattern that income is positively related to the demand for life insurance, supporting hypotheses H1d. 
Table 6. One way ANOVA: Income and demand for life insurance

\begin{tabular}{lcccc}
\hline Income Level & $\mathrm{N}$ & Mean & Std. Deviation & Std. Error \\
\hline Less than RM 1,000 & 8 & 1053.8750 & 670.17406 & 236.94231 \\
RM 1,000 to RM 1,999 & 47 & 893.1915 & 596.98924 & 87.07983 \\
RM 2,000 to RM 2,999 & 93 & 1233.3656 & 760.10961 & 78.81970 \\
RM 3,000 to RM 3,999 & 38 & 1363.3947 & 800.84079 & 129.91353 \\
RM 4,000 to RM 4,999 & 67 & 1512.7463 & 838.08008 & 102.38778 \\
RM 5,000 and above & 6 & 2217.8333 & 691.06596 & 282.12650 \\
Total & $\mathbf{2 5 9}$ & 1280.2471 & 792.36105 & 49.23492 \\
\hline
\end{tabular}

DV: LI_DEMAND, F= 5.861, Sig $=.000$

\subsubsection{Determinants of Life Insurance}

This section presents the results of a multiple regression analysis on the demand for life insurance, as shown in Table 7.

Table 7. Multiple regression on life insurance demand

\begin{tabular}{lccc}
\hline \multicolumn{1}{c}{ Independent Variables } & Standardized Coefficients & $\mathrm{t}$ & Sig. \\
\hline (Constant) & & .019 & .985 \\
FIN_LIT & .012 & 0.282 & .779 \\
PREC & .234 & 5.495 & .000 \\
LC & .275 & 7.222 & .000 \\
BEQUEST & .301 & 7.483 & .000 \\
WEALTH_ACC & .552 & 13.832 & .000 \\
\hline DV:
\end{tabular}

The overall results of the multiple regression show that the Adj. $R^{2}$ is $0.659(F=100.814, p=0.000)$ suggesting that the independent variables explain quite a substantial portion of the variance in the dependent variable. Findings reveal that all motives were significantly related to LI_DEMAND, hence, hypotheses $\mathrm{H} 2 \mathrm{a}-\mathrm{H} 2 \mathrm{~d}$ are accepted. It can be seen from Table 7 that the impact of WEALTH_ACC is the highest $(\beta=0.552, \mathrm{p}=0.000)$, followed by BEQUEST $(\beta=0.301, \mathrm{p}=0.000), \operatorname{LC}(\beta=0.2755, \mathrm{p}=0.000)$ and $\operatorname{PREC}(\beta=0.234, \mathrm{p}=0.000)$. Overall, results suggest that all saving motives significantly influence life insurance demand, with wealth accumulation motives as the strongest determinant. However, FIN_LIT did not have a significant relationship with LI_DEMAND $(\beta=0.012, \mathrm{p}=0.779)$, therefore rejecting hypotheses $\mathrm{H} 3$ which postulates a positive relationship between financial literacy and life insurance demand. This suggests that life insurance demand is not affected by the degree of financial literacy of individuals.

\section{Discussion and Conclusion}

This study examined the determinants of life insurance demand, namely, socio-demographic variables, saving motives and financial literacy. Results revealed that all socio-demographic variables and saving motives had a significant impact on life insurance demand. These results have important implications for life insurance companies in their marketing of life insurance products. For example, single individuals were found to have the highest demand for life insurance, as opposed to married and divorced people. Although this finding contradicts those of Dorfman and Adelman (2002), a possible explanation behind this is that single individuals have less financial commitments, hence, have excess funds to allocate in life insurance. Therefore, single individuals would appear to be a good target market for life insurance policies, since the sample in this study reveals higher life insurance holdings. Insurance companies could target to this group of consumers policies with attractive wealth accumulation benefits, since results also show that wealth accumulation motives are the strongest 
amongst the four saving motives.

This study shows that education level is significantly related to life insurance demand, where individuals with higher levels of education have higher life insurance demand. This finding supports Li et al. (2007) and implies that people who are more educated are more aware of the benefits of life insurance, and may possibly have easier access to life insurance through banks and financial intermediaries as opposed to those with low levels of education. Hence, life insurance companies should increase marketing efforts targeted to those less educated and increase penetration of insurance among these individuals.

Income was found to be positively related to the demand for life insurance. Naturally, marketers of life insurance would focus marketing efforts on individuals who have higher income, since these are the individuals who can afford to purchase more life insurance. However, although this is the case, low income earners should not be neglected as these individuals are the ones who most probably are the least protected. Insurance companies should emphasize the importance of life insurance to this group of individuals and promote term life insurance which is relatively cheaper as opposed to whole life insurance or investment-linked policies. With lower insurance premium, low income earners would be able to afford protection and penetration of life insurance in Malaysia would ultimately increase.

Results of the study found that all saving motives significantly influenced life insurance demand. Wealth accumulation motive was found to have the strongest impact on life insurance demand, followed by bequest, life cycle and precautionary motives. These results are interesting as one might expect bequest or precautionary motives to have a stronger impact on life insurance demand rather than wealth accumulation motives. Plausibly, these findings suggest that Malaysians perceive life insurance as a secured and long-term measure of accumulating wealth, due to strong and prudent financial track record of the major life insurance companies in Malaysia. Life insurance companies should take note of these results and design life insurance policies with attractive elements of returns and savings, since this study has found that individuals' life insurance demand is strongly influenced by wealth accumulation motives. Nonetheless, the other saving motives were also found to be significantly related to life insurance demand. Therefore, life insurance companies should simultaneously highlight the bequest, life cycle and precautionary aspects of life insurance when promoting their products and services.

An important finding of this study revealed that financial literacy had no impact on life insurance demand. This suggests that regardless of whether or not individuals are financially literate, they could still be sensitive to insecurities in life and demand for life insurance.

This study can be regarded as a preliminary study investigating the effects of saving motives on life insurance demand in Malaysia. However, since a convenience sampling method was employed on policyholders of five life insurance companies in Kuala Lumpur, results cannot be generalized to the entire Malaysian population. There is ample room for other researches to be carried out on other parts of Malaysia, especially more underdeveloped, rural areas, where life insurance penetration can be expected to be low. Such research efforts would allow life insurance companies make better generalizations of the Malaysian population and facilitate the efforts of increasing life insurance demand throughout the nation. Other aspects of life insurance demand should also be studied, for example, on other behavioral aspects of financial decision-making, such as heuristics and risk aversion.

\section{References}

Beck, T., \& Webb, I. (2003). Economic, Demographic, and Institutional Determinants of Life Insurance Consumption across Countries. The World Bank Economic Review, 17(1), 51-88. Retrieved from http://www.iifdc.org/pubs/Beck+Webb.pdf http://dx.doi.org/10.1093/wber/lhg011

Bernheim, B. D. (1991). How Strong Are Bequest Motives? Evidence Based on Estimates of the Demand for Life Insurance and Annuities. Journal of Political Economy, 99(5), 899-927. Retrieved from http://www.jstor.org/stable/10.2307/2937652 http://dx.doi.org/10.1086/261783

Bernheim, B. D., Shleifer, A., \& Summers, L. H. (1985). The strategic bequest motive. Journal of Political Economy, 93(6), 1045-1076. Retrieved from http://www.jstor.org/stable/10.2307/1833175 http://dx.doi.org/10.1086/261351

Delafrooz, N., \& Paim, L. H. (2011). Determinants of Saving Behaviour and Financial Problem among Employees in Malaysia. Australian Journal of Applied and Basic Science, 5(7), 222-228. Retrieved from http://www.ajbasweb.com/ajbas/2011/July-2011/222-228.pdf

Dhesi, D. (2012). Bullish Outlook: Life insurance industry to grow by between $7 \%$ and $10 \%$. The Star. Retrieved 
February 11, 2013, from http://www.liam.org.my/pdfs/THE_STAR_190312.pdf

Diacon, S., \& Mahdzan, N. S. (2009). Protection Insurance and Financial Wellbeing. A monograph written for the Financial Services Research Forum. London, UK. Retrieved from http://www.nottingham.ac.uk/business/forum/documents/researchreports/paper55.pdf

Dorfman, M. S., \& Adelman, S. W. (2002). An Analysis of the Quality of Internet Life Insurance Advice. Risk Management and Insurance Review, 5, 135-154. Retrieved from http://onlinelibrary.wiley.com/doi/10.1111/1098-1616.00012/abstract

http://dx.doi.org/10.1111/1098-1616.00012

Fitzgerald, J. (1987). The Effects of Social Security on Life Insurance Demand by Married Couples. The Journal of Risk and Insurance, 54(1), 86-99. Retrieved from http://www.jstor.org/stable/252883 http://dx.doi.org/10.2307/252883

Hubbard, R. G., Skinner, J., \& Zeldes, P. (1995). Precautionary Saving and Social Insurance. Journal of Political Economy, $\quad$ 103(2), 360-399. $\quad$ Retrieved from http://www.jstor.org/sici?sici=0022-3808\%28199504\%29103\%3A2\%3C360\%3APSASI\%3E2.0.CO\%3B2B\&origin=repec http://dx.doi.org/10.1086/261987

Li, D., Moshirian, F., Nguyen, P., \& Wee, T. (2007). The Demand for Life Insurance in OECD Countries. Journal of Risk and Insurance, 74, 637-652. Retrieved from http://onlinelibrary.wiley.com/doi/10.1111/j.1539-6975.2007.00228.x/abstract http://dx.doi.org/10.1111/j.1539-6975.2007.00228.x

LIAM. (2011). Teamwork: The Way Forward. In Malaysian Insurance Institute feature interview by Ghazali, Z. and Seow, M. L. $\quad$ Retrieved from http://insurance.com.my/download/Pages\%20from\%20Insurance\%2009\%202011\%20\%5BAug-Sep\%5D\% 20Web\%20Pg\%2016-17.pdf

Liebenberg, A. P., Carson, J. M., \& Dumm, R. E. (2011). A Dynamic Analysis of the Demand for Life Insurance. Journal of Risk and Insurance. Retrieved from http://onlinelibrary.wiley.com/doi/10.1111/j.1539-6975.2011.01454.x/full

Lusardi, A., Mitchell, O., \& Curto, V. (2010). Financial Literacy among the Young. Journal of Consumer Affairs, 44(2), 358-380. Retrieved from http://onlinelibrary.wiley.com/doi/10.1111/j.1745-6606.2010.01173.x/pdf http://dx.doi.org/10.1111/j.1745-6606.2010.01173.x

Modigliani, F., \& Brumberg, R. (1954). Utility analysis and the consumption function: an interpretration of cross section data. In K. Kurihara (Ed.), Post-Keynesian Economics. New Brunswick, NJ: Rutgers University Press.

Raza, A., Farhan, M., \& Akram, M. (2011). A Comparison of Financial Performance in Investment Banking Sector in Pakistan. International Journal of Business and Social Science, 2(9), 72-81.

Shafii, Z., Abiddin, Z., \& Ahmad, A. R. (2009). Ethnic Heterogeneity in the Malaysian Economy: A Special Reference to the Ethnic Group Participation in Financial Planning Activities. Journal of International Social Research, 2(8), 394-401. Retrieved from http://www.sosyalarastirmalar.com/cilt2/sayi8pdf/shafii_norhasni_ahmad.pdf

Todd, P. (2004). Integrative Life insurance Need Analysis. Journal of Society of Financial Service Professionals. Retrieved from http://connection.ebscohost.com/c/articles/12400365/integrative-life-insurance-needs-analysis

Truett, D. B., \& Truett, L. J. (1990). The Demand for Life Insurance in Mexico and the United States: A comparative study. Journal of Risk and Insurance, 57, 321-328. http://dx.doi.org/10.2307/253306

Wärneryd, K. E. (1999). The Psychology of Saving: A study on Economic Psychology. Glos: Edward Elgar.

Yaari, M. E. (1965). Uncertain Lifetime, Life Insurance and the Theory of the Consumer. The Review of Economic Studies, 32(2), 137-150. http://dx.doi.org/10.2307/2296058

Zietz, E. N. (2003). An Examination of the Demand for Life Insurance. Risk Management and Insurance Review, 6(2), 159-191. Retrieved from http://onlinelibrary.wiley.com/doi/10.1046/J.1098-1616.2003.030.x/abstract http://dx.doi.org/10.1046/J.1098-1616.2003.030.x 